Article

\title{
The Quality of Training Staff for the Digital Economy of Russia within the Framework of STEAM Education: Problems and Solutions in the Context of Distance Learning
}

\author{
Tatyana Anisimova ${ }^{1, *}$, Fairuza Sabirova ${ }^{2}$, Olga Shatunova ${ }^{3}$, Tatyana Bochkareva ${ }^{3}$ and Vladimir Vasilev ${ }^{4}$ \\ 1 Department of Mathematics and Applied Informatics, Elabuga Institute, Kazan Federal University, \\ 423600 Elabuga, Russia \\ 2 Department of Physics, Elabuga Institute, Kazan Federal University, 423600 Elabuga, Russia; \\ fasabirova377@rambler.ru \\ 3 Department of Education, Elabuga Institute, Kazan Federal University, 423600 Elabuga, Russia; \\ oshatunova22@rambler.ru (O.S.); tabochkareva9@rambler.ru (T.B.) \\ 4 Department of Economics and Management, Elabuga Institute, Kazan Federal University, \\ 423600 Elabuga, Russia; vlavasilev57@rambler.ru \\ * Correspondence: tanisimova11@rambler.ru
}

check for

updates

Citation: Anisimova, T.; Sabirova, F.; Shatunova, O.; Bochkareva, T.; Vasilev, V. The Quality of Training Staff for the Digital Economy of Russia within the Framework of STEAM Education: Problems and Solutions in the Context of Distance Learning. Educ. Sci. 2022, 12, 87. https://doi.org/10.3390/ educsci12020087

Academic Editor: Randall S. Davies

Received: 30 November 2021

Accepted: 10 January 2022

Published: 26 January 2022

Publisher's Note: MDPI stays neutral with regard to jurisdictional claims in published maps and institutional affiliations.

Copyright: (C) 2022 by the authors. Licensee MDPI, Basel, Switzerland. This article is an open access article distributed under the terms and conditions of the Creative Commons Attribution (CC BY) license (https:// creativecommons.org/licenses/by/ $4.0 /)$.

\begin{abstract}
The purpose of this study is to analyze the problems of quality training of personnel for the digital economy of Russia during the pandemic within the framework of STEAM education and to identify their solutions with the help of the most effective distance learning tools. The research is based on a survey of 138 respondents (students of the Department of Mathematics and Natural Sciences of the Yelabuga Institute of the Kazan Federal University), who have mastered professional competencies in a distance learning format during the pandemic. The results of the survey confirmed the conclusion that distance learning tools such as Moodle, Google Classroom, and Microsoft Teams have shown their effectiveness and can be successfully used not only in the context of extreme situations, for example, a pandemic, but also as elements of blended learning while bringing variety to the forms of learning, and thereby strengthening the process of training STEAM education specialists. The scientific novelty of the study lies in a deep analysis of the distance learning tools used for training specialists for the digital economy of Russia, namely STEAM education specialists, based on the collection of information from students during the period of transformational changes in the pedagogical education system.
\end{abstract}

Keywords: digital economy; digital technologies; distance learning; quality of education; STEAM education

\section{Introduction}

The digitalization of all spheres of life in modern post-industrial society seems to be progressive, inevitable, and contradictory [1-4]. For Russia, digitalization is important not only due to its geopolitical interests and military claims to membership in the club of world powers, but also due to the ample opportunities for increasing labor productivity, the transition from a commodity exporter model to an innovative development model, as well as in connection with negative demographic trends [5].

Russia's transition to a new technological order, i.e., to the digital economy model, requires competent personnel training. One of the fundamental factors in solving the problem of training personnel for the digital economy is the availability of highly qualified specialists with a set of professional competencies in field-specific areas, who are capable of applying interdisciplinary knowledge at the intersection of technical, economic, managerial, and humanitarian training. The preparation of such specialists requires revision of existing educational programs and approaches to their implementation, including the introduction of distance learning technologies, modernization of laboratory facilities, and strengthening the practical orientation of the educational process [6]. 
In this regard, changes in the requirements for the conduct of professional specialists' preparation in the context of digitalization are quite natural [7]. The formation of a personnel infrastructure for digital modernization of the economy requires standardization of the digital personnel training process [8], which can be built on the basis of available master's degree programs and the classification of personnel according to the criteria of functions performed for the use of digital technologies, such as technical specialists and single-subject specialists [9].

In contrast, it is impossible to solve the problem of competent personnel training without changing the approach to teaching, which implies modernization of the whole educational system [10]. The creation of a digital learning environment requires the widespread implementation and effective application of digital tools for educational activities, their inclusion in the information environment, as well as the provision of life-long learning opportunities based on an individual curriculum, which can be studied regardless of time and place. In digital-intensive industries, competency sets are of particular importance. Employees must have not only basic skills to perform specific tasks, but also complex problem solving, critical thinking, and creative skills.

One of the main problems associated with training personnel for the digital economy is improving the quality of education based on maintaining its fundamentality and meeting the current and future needs of individuals, society, and the state. Today, high-quality education determines the competitiveness of both individual institutions and the national education system as a whole [11]. Education must quickly respond to the challenges of the time in order to improve its quality. The solution to the problem of quality education depends on the timely and adequate response of the education system to the needs of society, changes in the external environment, and social order [12]. It is necessary to choose effective methods and technologies corresponding to these changes and needs.

Studies considering the potential of the education system in Russia and the ways to update it in order to improve the quality of education in the digital economy environment $[13,14]$ showed that the education system in Russia generally takes into account the trends of economy digitalization when creating material and technical conditions for the implementation of educational programs. However, there are personnel risks and risks of low applicability of material and technical support in educational activities, which considerably limits the potential of the Russian education system in training personnel for the digital economy. Therefore, a new standard of education should be discussed; the quality of this education can be improved through the use of distance technologies, which significantly transform the educational environment.

Distance learning is becoming increasingly popular in Russia and around the world. Its foremost advantage, which attracts more and more attention, is the possibility for students to gain knowledge from anywhere according to their individual schedules while having a set of training resources and the possibility of contacting the teacher [15]. This ensures a flexible learning format, which was one of the educational trends in 2021 [16].

To identify ways to improve the distance learning system in higher education as an important element of future specialists' training-which takes into account temporary and long-term tasks of the country's economic development-two main approaches to the digital economy can be distinguished: the classical approach, based on digital technologies, and the extended approach, based on economic production with the use of digital technologies [17]. To improve the quality of the educational process, it is necessary to use a whole range of resources, which are expected to meet relevant requirements of the modern education system. These resources include educational, personnel, functional, and technical ones.

Distance learning has a number of advantages, the main ones being accessibility, efficiency, a variety of learning forms, saving time and money, development of communication skills, learning efficiency, etc. The current disadvantages of distance learning include the inaccessibility of educational programs developed by some universities in the educational environment; a lack of uniform criteria (in terms of price and quality of training) for the 
assessment of educational programs; a lack of uniform approaches to terminology and definitions; a lack of qualified analysis and review of distance learning experience in the Russian Federation, as well as its regulatory framework, etc.

The implementation of STEAM education is considered to be one of the ways of improving the quality of preparation of future digital economy specialists. STEAM is based on the STEM approach, which involves science, technology, engineering, mathematics, and art, and means anything that is associated with creative activities and a creative approach to the solution of educational problems [18]. The process of training specialists within the framework of STEAM education is based on project and creative activities, which should be implemented mainly through contact learning tasks aimed at the development of creative skills [19]. Let us consider how distance learning can improve the quality of training personnel for the digital economy of Russia within the framework of STEAM education, through the example of the Yelabuga Institute of the Kazan Federal University (EI KFU).

In the EI KFU, within the framework of master's degree programs in the field of study "44.04.01 pedagogical education (profiles: educational robotics, digital education, engineering pedagogy)", rising STEAM teachers are trained [20,21]. The master's degree program profiles above confirm the opinion that the rapid evolution of technologies leads to the fact that soon the most popular and progressive specialists will be programmers, IT specialists, engineers, high-tech professionals, etc., [22].

Let us consider what educational platforms and services for studying individual disciplines of the master's degree programs within STEAM education are the most effective in the context of distance learning.

One of the most important disciplines that contributes to the development of important competencies in STEAM teachers is digital literacy; this discipline is focused on the formation of students' competencies in the field of digital consumption, the use of digital technologies, and digital security. To teach graduate students this discipline, we propose the use of the Google Classroom and Microsoft Teams tools. The pandemic has increased the popularity of online learning and Google Classroom is widely used by educational institutions as a platform for distance learning [23]. In our case, it can be used as a means of the theoretical preparation of undergraduates for the implementation of digital education for schoolchildren. The solution to this problem will be facilitated by the completion of various tasks by students; the performance of students will make it possible to assess the level of their digital competencies.

The second tool is the Microsoft Teams platform, which is an easy-to-use reference platform [24] and contributes to an increase in learning efficiency [25]. This platform can be used as a platform for discussion and collective analysis of various ways of developing digital literacy among students, as well as their parents and teachers. The options offered by students for the interaction of all educational process participants with the help of this digital resource to solve the problems of digital education and the formation of digital literacy can be analyzed collectively.

It is also possible to organize teamwork using the Moodle or Microsoft Teams platforms when studying the discipline "fundamentals of project activities", which plays an important role in the preparation of STEAM teachers. Research indicates that Moodle is often used to deliver course content and plan, assign grades, create assignments, collect course feedback, and communicate with course participants. Only a few of several functions, such as the assignment, feedback, quiz, and seminar modules, are considered very important and are actively used. The Moodle platform can increase the motivation to learn and improve the quality of learning while offering new opportunities for teaching, learning, and assessment $[26,27]$. For example, material on the history and theory of design, project classification, and design technology is supposed to be placed on the Moodle platform, where questions and tasks are also formulated. Group discussion of the stages of project activity and its implementation can be conducted on Microsoft Teams, as this platform allows users to directly communicate and jointly solve problems. The positive 
aspects of the platform include a user-friendly interface and the availability of its mobile application version.

The purpose of this study is to analyze the problem of high-quality training of personnel for the digital economy of Russia during the pandemic within the framework of STEAM education. The objectives of the study are explained by the need to identify the features of STEAM education and determine ways to solve the problem of high-quality training of personnel for the digital economy of Russia with the help of the most effective distance learning tools.

\section{Methods and Materials}

\subsection{Research Design and Sample}

A survey was conducted in 2021. The research involved 138 respondents (students of the Department of Mathematics and Natural Sciences of the Yelabuga Institute of the Kazan Federal University), who have mastered professional competencies in a distance learning format during the pandemic. Thirteen school teachers with 15-20 years of experience who took part in the International School Teachers' Festival were interviewed. Thus, the teacher selection criteria were work experience and participation in the festival.

\subsection{Survey}

The study consisted of two stages. In the first stage, the students were surveyed. The survey consisted of the following questions: "What classes did you have with the use of distance learning technologies and how often?"; "Assess the quality of digital resources"; "How, in your opinion, can the activity and interest of students be increased in the process of distance learning?"; "Assess the practical significance of digital resources"; "Which of the statements about distance learning do you agree the most?". The survey questionnaire was developed and formatted in Google Forms. Each experiment participant was sent a questionnaire by email with instructions on how to fill it in.

\subsection{Statistical Processing} of tables.

The students' responses were processed in Statistica and presented in the form

\subsection{Research Limitations}

The limitations of the study were associated with the small sample size, as the experiment involved one university, which was attended by a small number of students. Universities located in other countries have not been studied.

\subsection{Ethical Issues}

The experiment was carried out in compliance with all ethical standards and anonymity requirements; the respondents were not required to provide confidential information (name, surname, age, place of residence, etc.). Moreover, the research participants gave their written consent to conduct and process the data. At the same time, the students were asked to indicate the faculty in which they studied at the time of the survey.

\section{Results}

The responses to the question "What classes did you have with the use of distance learning technologies and how often?" were grouped and presented in Table 1. 
Table 1. Use of digital resources during the pandemic.

\begin{tabular}{|c|c|c|}
\hline No. & $\begin{array}{c}\text { Types of Activities Using Distance Learning } \\
\text { Technology }\end{array}$ & Number of Respondents, $\%$ \\
\hline 1 & Online classes in Microsoft Teams, Zoom, Skype, etc. & $\begin{array}{l}\text { often-69.6 } \\
\text { from time to time-30.4 } \\
\text { never- } 0\end{array}$ \\
\hline 2 & $\begin{array}{l}\text { Digital educational resources (DER) on the platform } \\
\text { of the Kazan Federal University }\end{array}$ & $\begin{array}{l}\text { often-62.3 } \\
\text { from time to time- }-30.4 \\
\text { never-7.2 }\end{array}$ \\
\hline 3 & $\begin{array}{c}\text { Online courses provided by other Russian } \\
\text { universities (on open educational } \\
\text { platforms/university platforms) }\end{array}$ & $\begin{array}{l}\text { often-20.3 } \\
\text { from time to time- }-47.8 \\
\text { never-31.9 }\end{array}$ \\
\hline
\end{tabular}

One of the key competencies that any teacher should develop is the ability to assess educational resources, as well as modify, create, and share digital resources and materials that are consistent with the learning objectives, the characteristics of the student group, and the teaching style [28].

The selection of digital resources by university teachers occurs according to the following criteria: reliability, quality, compliance, design, and interactivity. School teachers and university professors ( $41 \%$ and $44 \%$, respectively) compare resources on the Internet and are ready to give their colleagues advice on relevant resources and strategies for their search. Teachers aged $35-45(51 \%)$ and university professors under the age of $45(50 \%)$ are the most proficient with this issue [28].

The study used the same criteria to assess the quality of specific digital resources.

Each criterion was assessed on a 4-point scale:

1. 0 - the criterion has not been implemented (unsatisfactory).

2. 1-there have been isolated cases of the criterion implementation (satisfactory).

3. 2-the criterion has been partially implemented (good).

4. 3-the criterion has been fully implemented (excellent).

Thus, the results presented in Table 2 were obtained.

Table 2. The opinion of respondents about the quality of digital resources.

\begin{tabular}{|c|c|c|}
\hline No. & Type of Digital Resources & $\%$ of Respondents \\
\hline 1 & Online classes in Microsoft Teams, Zoom, Skype, etc. & $\begin{array}{c}\text { excellent-73.9 } \\
\text { good-24.6 } \\
\text { satisfactory-2.9 } \\
\text { unsatisfactory-0 }\end{array}$ \\
\hline 2 & $\begin{array}{l}\text { Digital educational resources (DER) on the platform } \\
\text { of the Kazan Federal University }\end{array}$ & $\begin{array}{c}\text { excellent-58.0 } \\
\text { good-34.8 } \\
\text { satisfactory-4.3 } \\
\text { unsatisfactory-2.9 }\end{array}$ \\
\hline 3 & $\begin{array}{c}\text { Online courses provided by other Russian } \\
\text { universities (on open educational } \\
\text { platforms/university platforms) }\end{array}$ & $\begin{array}{c}\text { excellent-40.6 } \\
\text { good-40.6 } \\
\text { satisfactory-7.2 } \\
\text { unsatisfactory-13.0 }\end{array}$ \\
\hline
\end{tabular}

The responses to the question "How, in your opinion, can the activity and interest of students be increased in the process of distance learning?" are described in Table 3. 
Table 3. Ways to increase the activity and interest of students in the process of distance learning.

\begin{tabular}{|c|c|c|}
\hline No. & $\begin{array}{l}\text { Ways to Increase the Activity and Interest of } \\
\text { Students }\end{array}$ & $\%$ of Respondents \\
\hline 1 & $\begin{array}{l}\text { Give more varied and interesting tasks to } \\
\text { consolidate and evaluate theoretical material }\end{array}$ & 60.9 \\
\hline 2 & Organize group work & 40.6 \\
\hline 3 & Introduce more video lectures & 37.7 \\
\hline 4 & $\begin{array}{c}\text { Use tasks that take into account different levels of } \\
\text { training of students }\end{array}$ & 31.9 \\
\hline 5 & $\begin{array}{c}\text { Strengthen teacher control over the quality and } \\
\text { timing of assignments }\end{array}$ & 15.9 \\
\hline
\end{tabular}

The respondents were asked to assess the practical significance of digital tools used by teachers in the educational process. The results are shown in Table 4.

Table 4. Respondents' assessment of the practical significance of the digital resources used by teachers.

\begin{tabular}{|c|c|c|}
\hline No. & Digital Tools Used by Educators & $\%$ of Respondents \\
\hline \multirow{4}{*}{1} & \multirow{3}{*}{$\begin{array}{l}\text { Lecture tools (Google Meet, Microsoft Teams, Zoom, } \\
\text { etc.) }\end{array}$} & I constantly use them -76.8 \\
\hline & & $\begin{array}{l}\text { I sometimes use them-20.4 } \\
\text { I rarely use them }-1.4\end{array}$ \\
\hline & & $\begin{array}{l}\text { I know them but never use- }-1.4 \\
\text { I do not know them-0 }\end{array}$ \\
\hline & \multirow{4}{*}{$\begin{array}{l}\text { Shared documents (Google Docs, Microsoft Office } \\
365 \text { Education, Perusall, etc.) }\end{array}$} & I constantly use them -66.7 \\
\hline \multirow[t]{3}{*}{2} & & $\begin{array}{l}\text { I sometimes use them }-24.6 \\
\text { I rarely use them }-5.8\end{array}$ \\
\hline & & I know them but never use -2.9 \\
\hline & & I do not know them -0 \\
\hline & & I constantly use them-50.8 \\
\hline \multirow{4}{*}{3} & \multirow{4}{*}{ Video services (YouTube, etc.) } & I sometimes use them-33.3 \\
\hline & & I rarely use them -10.2 \\
\hline & & I know them but never use -4.3 \\
\hline & & I do not know them -1.4 \\
\hline \multirow{4}{*}{4} & \multirow{4}{*}{$\begin{array}{c}\text { Text processors (Microsoft Word, Word Perfect, } \\
\text { Open Office, etc.) }\end{array}$} & I constantly use them- -68.1 \\
\hline & & $\begin{array}{l}\text { I sometimes use them-21.8 } \\
\text { I rarely use them }-5.8\end{array}$ \\
\hline & & $\begin{array}{l}\text { I know them but never use- }-4.3 \\
\text { I do not know them-0 }\end{array}$ \\
\hline & & I constantly use them- -66.7 \\
\hline \multirow{3}{*}{5} & \multirow{3}{*}{$\begin{array}{l}\text { Programs for preparing electronic presentations (MS } \\
\text { PowerPoint, Prezi, SlideRocket, VoiceThread, etc.) }\end{array}$} & I sometimes use them-29.0 \\
\hline & & \\
\hline & & I do not know them-0 \\
\hline \multirow{5}{*}{6} & \multirow{5}{*}{$\begin{array}{c}\text { Table processors (Microsoft Excel, Lotus, Quattro } \\
\text { Pro, etc.) }\end{array}$} & I constantly use them-50.7 \\
\hline & & I sometimes use them-34.9 \\
\hline & & I rarely use them -7.2 \\
\hline & & I know them but never use- -5.8 \\
\hline & & I do not know them-1.4 \\
\hline
\end{tabular}

The questionnaire contained a question determining the attitude of the respondents to the distance learning format: "Which of the statements about distance learning do you agree the most?". The responses obtained are presented in Table 5. 
Table 5. Attitude of respondents to the distance learning format.

\begin{tabular}{ccc}
\hline No. & Opinion of Respondents & \% of Respondents \\
\hline 1 & $\begin{array}{r}\text { I think that over time online (distance) learning will } \\
\text { completely replace face-to-face training }\end{array}$ & 36.2 \\
2 & $\begin{array}{c}\text { I think that online (distance) learning cannot replace live } \\
\text { communication with the teacher; it is impossible to assimilate } \\
\text { educational material without additional explanation } \\
\text { I think that the blended learning format is acceptable; some } \\
\text { material can be mastered independently using online } \\
\text { technologies and some information should be studied by }\end{array}$ & 21.7 \\
directly communicating with the teacher & 37.7 \\
\hline & I find it difficult to answer this question. & 4.3 \\
\hline
\end{tabular}

The results of the student survey indicate a high level of student involvement in distance learning, the use of digital resources, and a generally positive attitude towards the distance learning format.

Despite the high indicators, an educational course consisting of the thematic module "distance learning and modern technologies" was proposed (Figure 1). The course aimed to improve the quality and efficiency of distance learning and familiarize students with modern technologies for its implementation.

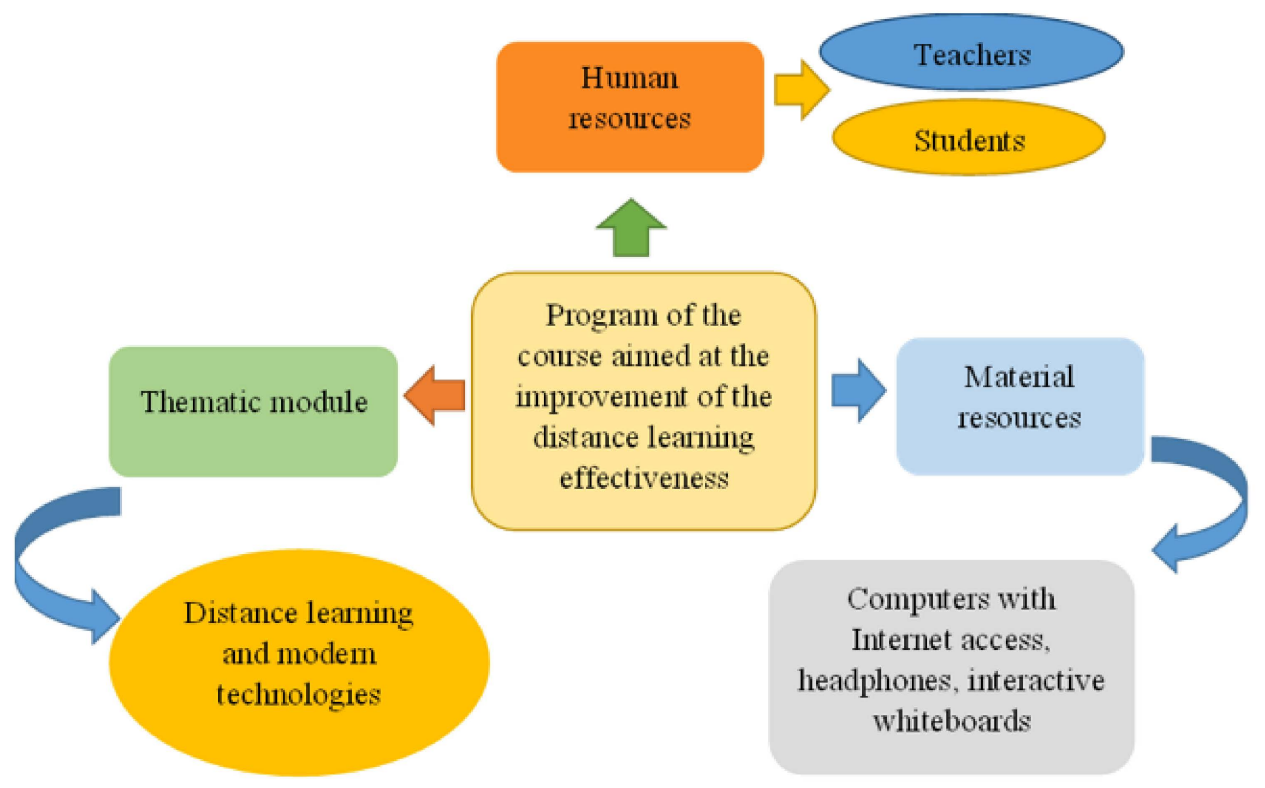

Figure 1. Course structure aimed at the improvement of the effectiveness of distance learning.

The developed course to improve the effectiveness of distance learning with the use of modern technologies consists of one thematic module- "distance learning and modern technologies" (Table 6).

The thematic module was divided into separate classes. Online content included e-books, articles, video and audio files, links to online courses on educational platforms, or other resources to explore distance learning opportunities. Thus, the developed course required the students and teachers to have a computer with access to the Internet and online platforms, headphones for watching videos, and an interactive board for visualizing theoretical materials. The teachers also familiarized the students with other educational platforms such as Coursera, EdX, and Khan Academy; the advantage of these platforms is the presentation of video content in English, which contributes to increasing language competence. 
Table 6. Content of the course aimed at the improvement of the effectiveness of distance learning.

\begin{tabular}{|c|c|c|c|c|}
\hline Thematic Module & & Tasks & & Resources Used \\
\hline $\begin{array}{c}\text { Distance learning } \\
\text { and modern } \\
\text { technologies }\end{array}$ & $\begin{array}{l}- \\
- \\
-\end{array}$ & $\begin{array}{l}\text { Formation and } \\
\text { development of skills in } \\
\text { the use of modern } \\
\text { technologies } \\
\text { Increasing the } \\
\text { effectiveness of } \\
\text { distance learning }\end{array}$ & $\begin{array}{l}- \\
- \\
-\end{array}$ & $\begin{array}{l}\text { Computers with Internet access, } \\
\text { headphones, interactive } \\
\text { whiteboards; } \\
\text { Teaching and Learning at a } \\
\text { Distance [29]; } \\
\text { Virtual Reality course on the } \\
\text { Coursera platform [30]; } \\
\text { E-Learning Ecologies: Innovative } \\
\text { Approaches to Teaching and } \\
\text { Learning for the Digital Age course } \\
\text { on the Coursera platform [31]; } \\
\text { Handbook of Research on Barriers } \\
\text { for Teaching 21st-Century } \\
\text { Competencies and the Impact of } \\
\text { Digitalization [32]; } \\
\text { Artificial Intelligence for all courses } \\
\text { on the Coursera platform [33]. }\end{array}$ \\
\hline
\end{tabular}

\section{Discussion}

The COVID-19 pandemic has led to serious disruptions in education systems around the world [34-36]. In contrast to the transition from face-to-face learning to blended learning, online learning, or a flipped classroom under normal circumstances, the emergency transition to distance learning due to the crisis was sudden and unplanned [37,38].

These problems and the ways to solve them were considered by many Russian and foreign researchers. Some of them [39] concentrated on the performance of higher education students during distance learning. Others noted that with a large number of guide books and teacher training sessions devoted to the organization of online learning and the use of digital tools, there was a decrease in the quality of teaching and an unwillingness of a significant proportion of teachers to work with continuously evolving technological tools $[40,41]$. The quality and quantity of educational resources required for the study of the discipline turned out to be either insufficient, if the university or the teacher had not been involved in this area of work before, or excessive, if students were asked to use all materials related to the relevant field of study that were available on recognized educational platforms, but without proper navigation [42].

In addition to the undoubted advantages, including the expansion of educational information, the ability to use educational content at a convenient time and in a convenient form, the ability to build individual educational trajectories, the improvement of educational system management tools, etc., the use of digital technologies in education can also lead to an education effectiveness drop as novel digital solutions are likely to simplify information perception mechanisms. They are not forcing a person to think creatively and reduce communication skills [43]. In relation to the digitalization of the Russian education system, it is constrained by technical and legal problems. While the first lie in the lack of digital skills among the majority of educators, the latter result from no clear delineation of "e-learning", "information technology", "distance learning technologies", and "information and educational environment" in the Russian legislation. Nevertheless, the experience of training during the pandemic, the results of the questionnaires, and teacher interviews showed that distance technologies could be a worthy alternative to conduct activities when training STEAM teachers.

\section{Conclusions}

The results of the study indicate that the current changes observed around the world require the education system to train specialists capable of solving the problems of the digital economy and possessing the appropriate competencies, including in the field of STEAM. In these conditions, the issue of the quality of education becomes relevant; one of 
the ways to improve the quality of training is to use distance learning technologies, which significantly transform the educational environment.

The COVID-19 pandemic has demonstrated that educational organizations should adapt to the new scenarios and formats of learning at all stages of education. In Russia, the most popular distance learning platforms are Google Meet, Microsoft Teams, and Zoom. Many universities have developed their own digital educational resources for online learning; these can be successfully used to train specialists in the field of STEAM education.

The practical significance and prospects for further research reside in the fact that the outlined advantages and disadvantages of distance learning in the context of STEAM education can be used to improve the quality of learning.

Author Contributions: Conceptualization, F.S. and O.S.; methodology, T.A. and T.B.; software, F.S. and V.V.; validation, T.A., F.S., O.S., T.B. and V.V.; formal analysis, T.A.; investigation, V.V.; resources, O.S. and T.B.; data curation, O.S. and V.V.; writing—original draft preparation, T.A. and T.B.; writingreview and editing, F.S. and V.V.; visualization, T.B.; supervision, T.A.; project administration, F.S.; funding acquisition, O.S. All authors have read and agreed to the published version of the manuscript.

Funding: The reported study was funded by RFBR, project number 19-29-07037.

Institutional Review Board Statement: Not applicable.

Informed Consent Statement: Not applicable.

Data Availability Statement: Not applicable.

Conflicts of Interest: The authors declare no conflict of interest.

\section{References}

1. Alekseev, A.; Katasev, A.; Kirillov, A.; Khassianov, A.; Zuev, D. Prototype of classifier for the decision support system of legal documents. In CEUR Workshop Proceedings, Proceedings of the 21th Scientific Conference "Scientific Services E Internet-2019", Novorossiysk-Abrau, Russia, 23-28 September 2019; CEUR: Novorossiyk-Abrau, Russia, 2020; Volume 2543, pp. 328-335.

2. Kildeeva, S.S.; Katasev, A.S.; Talipov, N.G. Models and methods of forecasting and tasks distribution by performers in electronic document management systems. In Society 5.0: Cyberspace for Advanced Human-Centered Society; Springer International Publishing: Cham, Switzerland, 2021; pp. 57-71. [CrossRef]

3. Makhmutova, A.; Anikin, I. Online clustering on uncertain data stream. J. Phys. Conf. Ser. 2019, 1189, 012025. [CrossRef]

4. Rastorguev, S.V.; Tyan, Y.S. Digitalization of the Russian economy: Trends, personnel, platforms, challenges to the state. Public Opin. Monit. Econ. Soc. Chang. 2019, 5, 136-161.

5. Agumbayeva, A.; Chmyshenko, E.; Pulyaev, N.; Bunkovsky, D.; Kolesov, K.; Amirova, E. Industrial transformation of Kazakhstan in digitalization era. J. Adv. Res. Law Econ. 2019, 10, 1861-1867. [CrossRef]

6. Zvontsov, A.V. Peculiarities of training specialists in the digital transformation of the national economy. In Proceedings of the 2018 XVII Russian Scientific and Practical Conference on Planning and Teaching Engineering Staff for the Industrial and Economic Complex of the Region (PTES), St. Petersburg, Russia, 14-15 November 2018; IEEE: Piscataway, NJ, USA, 2018 ; pp. 191-192. [CrossRef]

7. Zvontsov, A.V.; Fomina, I.G. Transformation of training in the digitalization of the Russian economy. In Proceedings of the 2019 XVIII Russian Scientific and Practical Conference on Planning and Teaching Engineering Staff for the Industrial and Economic Complex of the Region (PTES), St. Petersburg, Russia, 20-21 November 2019; Eco Vector: Saint Petersburg, Russia, 2019; pp. 114-116. [CrossRef]

8. Gerasimova, E.B.; Kurashova, A.A.; Tipalina, M.V.; Bulatenko, M.V.; Tarasova, N.V. New state standards of higher education for training of digital personnel in the conditions of Industry 4.0. Horizon 2019, 27, 199205. [CrossRef]

9. Rudskoy, A.I.; Borovkov, A.I.; Romanov, P.I.; Kolosova, O.V. Ways to reduce risks when building the digital economy in Russia. Educational aspect. High. Educ. Russ. 2019, 28, 9-22. [CrossRef]

10. Gurfova, R.V.; Alikaeva, M.V.; Prigoda, L.V.; Karakaeva, E.U.; Mineva, O.K. Formation of a student's digital competencies based on a digital footprint. In Proceedings of the 2019 International Conference “Quality Management, Transport and Information Security, Information Technologies" (IT\&QM\&IS), Sochi, Russia, 23-27 September 2019; IEEE: Piscataway, NJ, USA, 2009; pp. 497-501. [CrossRef]

11. Markova, E.; Markov, Y. Quality system of education at higher educational institutions. Mod. Eur. Res. 2014, 4, 52-54.

12. Timofeeva, N.V.; Zadumina, N.A.; Yaroslavtseva, N.A.; Yaroslavtsev, A.S. The problem of the quality of education in modern school. Int. J. Appl. Fundam. Res. 2010, 9, 63-65. 
13. Mitrofanova, E.A.; Simonova, M.V.; Tarasenko, V.V. Potential of the education system in Russia in training staff for the digital economy. In Digital Transformation of the Economy: Challenges, Trends and New Opportunities. Advances in Intelligent Systems and Computing; Ashmarina, S., Mesquita, A., Vochozka, M., Eds.; Springer International Publishing: Cham, Switzerland, 2020; pp. 463-472. [CrossRef]

14. Zhukovskaya, I.E. The main trends in improving the activities of a higher educational institution in the context of digital transformation. Open Educ. 2021, 25, 15-25. [CrossRef]

15. Otrokhova, O.A. Distance education and regulatory framework. Pedagogical workshop. Everything Teach. 2014, 10, 10-12.

16. Semeshkina, M. Trends in Education for 2021. Expert. 2021. Available online: https://expert.ru/2021/01/23/trendi-vobrazovanii-na-2021-god/ (accessed on 13 October 2021).

17. Arsenieva, N.V.; Putyatina, L.M.; Uglova, L.N. Development of digital educational environment in higher education. In Proceedings of the SHS Web of Conferences: III International Scientific and Practical Conference "Modern Management Trends and the Digital Economy: From Regional Development to Global Economic Growth" (MTDE 2021), Yekaterinburg, Russia, 15-16 April 2021; EDP Sciences: Les Ulis, France, 2021; Volume 106, p. 03002. [CrossRef]

18. Frolov, A.V. Reform of the US innovation system: From STEM to STEAM education. Alma Mater 2013, 1, $101-105$.

19. Aguilera, D.; Ortiz-Revilla, J. Stem vs. Steam education and student creativity: A systematic literature review. Educ. Sci. 2021, 11, 331. [CrossRef]

20. Anisimova, T.I.; Bochkareva, T.N.; Shatunova, O.V. STEAM in training personnel for the digital economy. Mod. Sci. 2020, 2, 37-43.

21. Anisimova, T.I.; Sabirova, F.M.; Shatunova, O.V. Training of teachers for STEAM education. High. Educ. Today 2019, 6, 31-35.

22. Grebenyuk, T.B.; Bulan, I.G. The use of the STEM approach in the context of vocational secondary education. Bull. Balt. State Acad. Fish. Fleet: Psychol. Pedagog. Sci. 2020, 1, 22-29.

23. Swaminathan, N.; Govindharaj, P.; Jagadeesh, N.S.; Ravichandran, L. Evaluating the effectiveness of an online faculty development programme for nurse educators about remote teaching during COVID-19. J. Taibah Univ. Med. Sci. 2021, 16, 268-273. [CrossRef]

24. Pal, D.; Vanijja, V. Perceived usability evaluation of Microsoft Teams as an online learning platform during COVID-19 using system usability scale and technology acceptance model in India. Child. Youth Serv. Rev. 2020, 119, 105535. [CrossRef] [PubMed]

25. Aulakh, G.S.; Duggal, S.; Sutton, D. Findings from an OMFS journal club: Is COVID-19 the catalyst we have needed to embrace technology? Br. J. Oral Maxillofac. Surg. 2020. [CrossRef]

26. Deepak, K. Evaluation of Moodle features at Kajaani University of applied sciences. Procedia Comput. Sci. 2017, 116, 121-128 [CrossRef]

27. Oproiu, G.C. A study about using e-learning platform (Moodle) in university teaching process. Procedia-Soc. Behav. Sci. 2015, 180, 426-432. [CrossRef]

28. Aimaletdinov, T.A.; Baimuratova, L.R.; Zaitseva, O.A.; Imaeva, G.R.; Spiridonova, L.V. Digital literacy of Russian teachers In Readiness to Use Digital Technologies in the Educational Process; NAFI Publishing House: Moscow, Russia, 2019.

29. Simonson, M.; Zvacek, S.M.; Smaldino, S. Teaching and Learning at a Distance: Foundations of Distance Education, 7th ed.; Information Age Publishing: Charlotte, NC, USA, 2019.

30. Coursera. Virtual Reality. 2021. Available online: https://www.coursera.org/specializations/virtual-reality (accessed on 13 October 2021).

31. Coursera. E-Learning Ecologies: Innovative Approaches to Teaching and Learning for the Digital Age. 2021. Available online: https: / / ru.coursera.org/learn/ elearning (accessed on 13 October 2021).

32. Dhir, H.K. Handbook of Research on Barriers for Teaching 21st-Century Competencies and the Impact of Digitalization; IGI Global: Hershey, PA, USA, 2021. [CrossRef]

33. Coursera. Artificial Intelligence for All. 2021. Available online: https://www.coursera.org/learn/ai-for-everyone (accessed on 13 October 2021)

34. Al-Karaki, J.N.; Ababneh, N.; Hamid, Y.; Gawanmeh, A. Evaluating the effectiveness of distance learning in higher education during COVID-19 global crisis: Uae educators' perspectives. Contemp. Educ. Technol. 2021, 13, ep311. [CrossRef]

35. Johnson, J.B.; Reddy, P.; Chand, R.; Naiker, M. Attitudes and awareness of regional Pacific Island students towards e-learning. Int. J. Educ. Technol. High. Educ. 2021, 18, 13. [CrossRef] [PubMed]

36. Selvaraj, A.; Radhin, V.; Nithin, K.A.; Benson, N.; Mathew, A.J. Effect of pandemic based online education on teaching and learning system. Int. J. Educ. Dev. 2021, 85, 102444. [CrossRef] [PubMed]

37. Crompton, H.; Burke, D.; Jordan, K.; Wilson, S.W.G. Learning with technology during emergencies: A systematic review of K-12 education. Br. J. Educ. Technol. 2021, 52, 1554-1575. [CrossRef]

38. Dietrich, N.; Kentheswaran, K.; Ahmadi, A.; Teychene, J.; Bessiere, Y.; Alfenore, S.; Laborie, S.; Bastoul, D.; Loubiere, K.; Guigui, C.; et al. Attempts, successes, and failures of distance learning in the time of COVID-19. J. Chem. Educ. 2020, 97, $2448-2457$. [CrossRef]

39. Iglesias-Pradas, S.; Hernández-García, Á.; Chaparro-Peláez, J.; Prieto, J.L. Emergency remote teaching and students' academic performance in higher education during the COVID-19 pandemic: A case study. Comput. Hum. Behav. 2021, 119, 106713. [CrossRef]

40. NTF. Impact of the COVID-19 Pandemic on Higher Education and Post-Graduate Studies: International, National, and Institutional Response. 2020. Available online: https://ntf.ru/sites/default/files/Vliyanie\%20pandemii\%20COVID-19\%20na\%20 sektor\%20vysshego\%20obrazovaniya\%20i\%20magistraturu.pdf (accessed on 13 October 2021). 
41. Andryukhina, L.M.; Sadovnikova, N.O.; Utkina, S.N.; Mirzaahmedov, A.M. Digitalisation of professional education: Prospects and invisible barriers. Educ. Sci. J. 2020, 22, 116-147. [CrossRef]

42. Sastre-Merino, S.; Nuñez, J.L.M.; Pablo-Lerchundi, I.; Nufiez-del-Rio, C. Training STEAM educators in the COVID-19 emergency situation: Redesigning teaching. In Proceedings of the 2020 Sixth International Conference on e-Learning (ECONF), Sakheer, Bahrain, 6-7 December 2020; IEEE: Piscataway, NJ, USA, 2020; pp. 72-75. [CrossRef]

43. Vorontsova, E.; Vorontsov, A. Digitalization of the Educational process: Problematic issues in the context of the development of the digital economy. In Proceedings of the 2019 International SPBPU Scientific Conference on Innovations in Digital Economy, St. Petersburg, Russia, 24-25 October 2019; ACM Digital Library: New York, NY, USA, 2019; pp. 1-7. [CrossRef] 